\title{
Cancer immunotherapy in mice and humans: personal observations*
}

\author{
Jerzy Kawiak
}

\begin{abstract}
Nalecz Institute of Biocybernetics and Biomedical Engineering, Polish Academy of Sciences, Warsaw, Poland
\end{abstract}

*This is an extended and updated version of a lecture presented at the $50^{\text {th }}$ Anniversary Symposium of the Polish Society for Histochemistry and Cytochemistry, 5-8 September 2016, Wojanów, Poland

\begin{abstract}
An experiment involving active immunotherapy of leukemia in mice and its extension to human patients with chronic lymphocytic leukemia is described. First, anticancer activation of the immune system, how it is achieved, and observations of the central blockade of the immune system in leukemia are discussed. Clinical results of antileukemia immune activation are then presented, along with a description of new attempts to remove the immune checkpoint blockade. Personal observations are presented on possible further steps to achieving more effective active immunotherapy of cancer. (Folia Histochemica et Cytobiologica 2018, Vol. 56, No. 1, 1-10)
\end{abstract}

Key words: apoptosis; L1210 leukemia cells; DBA/2 mice; thymus; human B-CLL; vaccination with apoptotic CLL lymphocytes; clinical trial

\section{Introduction}

Immune responses to mutation events within cells leading to cancer or microbial pathogens are organized by the interaction between cells of the innate and adaptive parts of the immune systems. One aspect of the adaptive immune system is its capacity to remember previous encounters with the same antigen. This could serve as a basis for constructing anticancer vaccines. The main theoretical basis of this therapy is the fact that almost every cell of the $10^{16}$ cells in the human body is monitored by the immune system, and virally infected or mutated cells are recognized and removed. The hypothesis suggests that further activation of the immune system would result in more effective removal of mutated cancer cells expressing tumor antigens (now called neoantigens) that are not present in the normal cells. They are recognized by

Correspondecne address: J. Kawiak

Nałęcz Institute of Biocybernetics and Biomedical

Engineering, Polish Academy of Sciences,

Księcia Trojdena 4, 02-109 Warsaw, Poland

e-mail: jkawiak@ibib.waw.pl
T cells differentiated in the thymus against the tumor neoantigens. Vaccination with tumor antigens present within cancer cells should increase the activation of actually present anti-tumor T-cells and lead to the activation of new ones, as the collection of tumor antigens changes during development of the tumor.

An experiment on an animal model was performed on DBA/2 mice treated with leukemia L1210 cells. The leukemia cells were cultured in vitro, essentially as described in the National Cancer Institute Program [1], and after implanting in the healthy animals, an acute leukemia process developed. It was assumed that the leukemia cells were syngeneic with DBA/2 mice, so the L1210 cell implantation was not an allogenic transplant. That was first tested by comparing MHC class I of the DBA/2 mice lymphocytes with L1210 cells [2], confirming the syngeneic character of the leukemia cells (Table 1). In the model, activation of the mouse immune system should target the L1210 leukemia cells.

The immune system may theoretically be activated by implanting a large quantity of leukemia cell antigens. The genetic instability of cancer cells is well known [3, 4], and so the best collection of L1210 
Table 1. Leukemia L1210 cells are syngeneic with the lymph node cells of DBA/2 mice. Result of the reaction with various antibodies against $\mathrm{H}-2$ alloantigens [2]

\begin{tabular}{|c|c|c|}
\hline \multirow[t]{2}{*}{ Antibody } & \multicolumn{2}{|c|}{ Cytotoxic titer } \\
\hline & $\begin{array}{c}\text { L1210 } \\
\text { cells }\end{array}$ & Lymph-node cells* \\
\hline anti $\mathrm{H}-2 \mathrm{~K}^{\mathrm{a}}$ & $\begin{array}{c}>80 \\
\text { (positive) }\end{array}$ & $>160$ \\
\hline anti $\mathrm{H}-2 \mathrm{D}^{\mathrm{d}}$ & $\begin{array}{c}>160 \\
\text { (positive) }\end{array}$ & $>160$ \\
\hline anti $\mathrm{H}-2 \mathrm{~K}^{\mathrm{b}}$ & $\begin{array}{c}0 \\
\text { (negative) }\end{array}$ & $\begin{array}{c}>>160 \\
\text { (negative control) }\end{array}$ \\
\hline anti $\mathrm{H}-2 \mathrm{D}^{\mathrm{b}}$ & $\begin{array}{c}0 \\
\text { (negative) }\end{array}$ & $\begin{array}{c}>160 \\
\text { (negative control) }\end{array}$ \\
\hline
\end{tabular}

*Lymphocytes taken from a strain of mouse of specified haplotype.

antigens would be from within the leukemia cells themselves. This hypothesis suggested induction of $T$ cell responses to the mouse leukemia cells antigens now called neoantigens which are absent in the normal cells [5]. Theoretically, a tumor surgically removed from a patient would constitute the best source of tumor antigens. However, the malignant antigenic tumor cells cannot be directly applied to induce anticancer immune responses. Moreover, dead, necrotic cells cannot be used to induce anticancer responses, because they are immediately recognized and removed by local inflammatory processes. Another argument against use of necrotic cells is that they release $\mathrm{K}^{+}$ions, which has been found to suppress the activity of the immune system's T cells [6]. Therefore, in the proposed animal model, leukemia antigens were applied in the form of leukemia cells with induced apoptosis. The induction of apoptosis in cells blocks their proliferation; however, the commencement of the apoptotic process is delayed in many cells. The cell apoptotic process begins several hours, or even some days, after induction [7-9]; however, the apoptotic process itself takes only about $2 \mathrm{~h}$ to proceed. A cell in apoptosis will be recognized by surrounding cells and immediately removed by phagocytosis. It appears that leukemia cells with induced apoptosis are a long-term antigen stimulating system that functions within days, without inducing an inflammatory response $[10,11]$.

\section{Anticancer activation of the immune system}

The first experimental test of the antigen properties of the system was in DBA/2 mice vaccinated with various doses of apoptosis-induced L1210 leukemia cells. It was expected that implantation of apoptotic
Table 2. Survival of mice with implanted malignant L1210 cells $\left(10^{3}\right.$ per animal $)$ one week earlier vaccinated with apoptotic or dead L1210 cells, compared to unvaccinated control animals [12]

\begin{tabular}{|l|c|c|c|}
\hline Number of cells & No. of animals & MST days & Range, days \\
\hline Control (-L1210CY) & 58 & 20 & $18-22$ \\
\hline L1210 dead, 10 & 10 & 19 & $17-21$ \\
\hline L1210CY $10^{3}$ & 10 & 18 & $14-22$ \\
\hline L1210CY $10^{4}$ & 10 & 32 & $20-51$ \\
\hline L1210CY $10^{5}$ & 10 & $66^{*}$ & $32-135$ \\
\hline
\end{tabular}

MST - Median Survival Time. *Statistically significant difference compared to unvaccinated control, $\mathrm{p}<0.05$.

cells would delay leukemia growth in the vaccinated mice. Apoptosis in L1210 cells was induced in vitro by treatment with cyclophosphamide or mafosfamide (a derivative of cyclophosphamide) (L1210CY or L1210Maf cells). The in vitro treatment of cells with cyclophosphamide or mafosfamide blocked the mitotic cycle within the cells, which were then used for vaccinating the mice. One week later, the mice were implanted with $10^{3}$ malignant L1210 leukemia cells in the logarithmic phase of growth [12]. Mice vaccinated with $10^{5} \mathrm{~L} 1210 \mathrm{CY}$ cells before the implantation of malignant L1210 cells survive the malignant leukemia significantly longer than mice not vaccinated, or vaccinated with dead leukemia cells (Table 2) [12]. This result suggests that the apoptotic L1210 cells are an effective antileukemia antigen. The effect was immunologically specific, as it did not prolong the survival of mice with malignant L-1 sarcoma cells.

In the next step of the experiment, we proceeded into the treatment of mice with already growing malignant leukemia [13]. The mice were intraperitoneally inoculated with 10 malignant L1210 leukemia cells, and their survival of the leukemia was observed. We found that i.p. inoculated L1210 cells induced the death of mice in an average of 12.5 days (median survival time; MST), while i.p. injection of $10^{6}$ or $10^{7}$ apoptotic L1210Maf cells at days $0,3,6$, 9, and 12 from start of the leukemia led to an MST of 13.5 days (Table 3 ). The vaccination was therefore ineffective over a period shorter than the full immunological response against the fast-growing leukemia. In order to prolong the survival of leukemic mice inoculated with malignant L1210 cells, chemotherapy with cyclophosphamide $(100 \mathrm{mg} / \mathrm{kg})$ was administered i.p. at day 8 , which resulted in a prolongation of the survival period to 19 days. When the mice treated with chemotherapy were vaccinated i.p. with $10^{7}$ apoptotic L1210Maf cells at 0, 3, 6, 9, and 
Table 3. Chemoimmunotherapy of L1210 leukemia in mice model [13]

\begin{tabular}{|c|c|c|c|c|c|}
\hline Group of mice & Leukemia & $\mathbf{C Y}$ & BRM & $\begin{array}{l}\text { L1210 Maf } \\
\text { Cells }\end{array}$ & $\begin{array}{c}\text { MST (range) } \\
\text { (Survivors/total) }\end{array}$ \\
\hline \multirow[t]{2}{*}{1} & + & - & - & - & $12.5(12.2-12.8)$ \\
\hline & & & & & $(0 / 54)$ \\
\hline \multirow[t]{2}{*}{2} & + & - & - & $10^{6}$ i.p. & $13.5(12.3-14.8)$ \\
\hline & & & & & $(0 / 10)$ \\
\hline \multirow[t]{2}{*}{3} & + & - & - & $10^{7}$ i.p. & $12.5(11.6-13.4)$ \\
\hline & & & & & $(0 / 10)$ \\
\hline \multirow[t]{2}{*}{4} & + & + & - & - & $19.0(18.5-19.5)^{\mathrm{a}}$ \\
\hline & & & & & $(3 / 56)$ \\
\hline \multirow[t]{2}{*}{5} & + & + & - & $10^{6}$ i.p. & $27.0(22.6-32.3)^{b}$ \\
\hline & & & & & $(6 / 20)^{b}$ \\
\hline \multirow[t]{2}{*}{6} & + & + & - & $10^{7}$ i.p. & $25.0(23.5-26.6)^{b}$ \\
\hline & & & & & $(17 / 60)^{\mathrm{c}}$ \\
\hline \multirow[t]{2}{*}{7} & + & + & - & $10^{7}$ i.p. + s.c. & $>100$ \\
\hline & & & & & $(16 / 30)^{\mathrm{de}}$ \\
\hline \multirow[t]{2}{*}{8} & + & + & + & $10^{7}$ i.p. + s.c. & $>100$ \\
\hline & & & & & $(6 / 10)^{\mathrm{b}}$ \\
\hline & & & & & \\
\hline
\end{tabular}

Leukemia: each mouse received 10 malignant L1210 cells i.p. at day 0. CY: $100 \mathrm{mg} / \mathrm{kg}$ of cyclophosphamide was injected i.p. eight days after L1210 leukemia challenge. BMR: BCG $\left(1 \mathrm{mg} / \mathrm{mouse}=3 \times 10^{6}\right.$ viable bacilli) were injected i.p. on days $0,+3,+6,+9,+12$ after L1210 leukemia challenge. L1210 Maf: the cells were injected on days $0,+3,+6,+9,+12$ after L1210 leukemia challenge. ${ }^{\text {ap }}<0.05$ as compared with group $1 ;{ }^{\text {b } p}<0.05$ as compared with group $4 ;{ }^{\mathrm{c}} \mathrm{p}<0.01$ as compared with group $4 ;{ }^{\mathrm{d}} \mathrm{p}<0.001$ as compared with group $4{ }^{\mathrm{e}} \mathrm{p}<0.05$ as compared with group 6 .

12 days (as described before), the MST was 25 days (28.3\% mice survival, 17 of 60$)$. These leukemic mice lived for 100 days or more from the time of inoculation with malignant cells. A 100-day survival period of mice can be taken as recovery of animals from malignant leukemia; most mice were observed for 2 years. The success rate could be increased to $53 \%$ (16 of 30$)$ by vaccination of the leukemia-inoculated mice with $10^{7}$ apoptotic L1210Maf cells given intraperitoneally and subcutaneously, and additional BCG (1 mg/mice) inoculation further increased the rate to $60 \%$ (6 of 10 ) of the leukemia-recovered animals. Thus, the experiment demonstrated the possibility of successful treatment of acute leukemia in an animal model by activation of the immune system [13] and as shown by further tests, even when cells were resistant to the cytoplasmic agents [14]. It can be suggested that, using an appropriate vaccination and additional cyclophosphamide chemotherapy, the number of antileukemia lymphocyte clones could be significantly increased to effectively attack the malignant leukemia cells in the mice.

\section{Leukemia blockade of the immune system}

The observation that only some of the vaccinated leukemic mice recovered suggests that the positive outcome was blocked by some mechanism in the nonrecovered animals. We thus decided to check the status of the thymus in the leukemic mice, in cooperation with HJ Seidel of the Department of Clinical Physiology and Occupational Medicine, University of Ulm, Germany. The plan was to test thymocyte differentiation in vivo in DBA/ 2 mice with L1210 leukemia. Within the first 3-6 days after i.p. implantation of $10^{6} \mathrm{~L} 1210$ cells, we found profound changes in thymocyte subpopulations. Microscope observations clearly showed that leukemia significantly altered the differentiation of $\mathrm{T}$ cells, centrally blocking the immunological response to malignant cells [15]. Shortly thereafter, we repeated the thymocyte test in leukemic animals and examined changes in thymocyte subpopulations by flow cytometry; the results of the observations agreed well with the microscopic observations (Table 4) [16]. 
Table 4. Subpopulations of thymocytes in leukemia-bearing mice or normal mice at different days after i.p. inoculation of $10^{6}$ L1210 malignant cells $[15,16]$

\begin{tabular}{|l|c|c|c|c|}
\hline \multirow{2}{*}{ Mice } & \multicolumn{3}{|c|}{ Subpopulation of thymocytes, percentage* } \\
\cline { 2 - 5 } & L3T4 $^{+}$Lyt 2 $^{+}$ & L3T4 $^{+}$Lyt 2 $^{-}$ & L3T4-Lyt 2 $^{+}$ & L3T4-Lyt 2- $^{-}$ \\
\hline Normal, $\mathrm{n}=7$ & $78.0 \pm 3.8$ & $10.7 \pm 2.0$ & $5.0 \pm 1.0$ & $6.6 \pm 1.8$ \\
\hline L1210, 2 d., $\mathrm{n}=2$ & $73.0 \pm 2.8$ & $14.0 \pm 1.4$ & $7.0 \pm 0$ & $5.5 \pm 0.7$ \\
\hline L1210, 3 d., $\mathrm{n}=5$ & $71.6 \pm 5.0$ & $13.8 \pm 1.9^{\mathrm{b}}$ & $6.8 \pm 0.4^{\mathrm{a}}$ & $7.8 \pm 2.8$ \\
\hline L1210, 5 d., $\mathrm{n}=4$ & $62.0 \pm 14.9^{\mathrm{b}}$ & $19.3 \pm 7.2$ & $9.3 \pm 2.1^{\mathrm{a}}$ & $9.5 \pm 5.4$ \\
\hline L1210, 6 d., $\mathrm{n}=6$ & $48.3 \pm 20.0^{\mathrm{b}}$ & $25.2 \pm 9.0$ & $11.2 \pm 5.3^{\mathrm{b}}$ & $15.8 \pm 7.8^{\mathrm{b}}$ \\
\hline
\end{tabular}

*Mean values $\pm \mathrm{SD} ; \mathrm{n}=$ number of animals in the group, difference as compared with normal mice; ${ }^{\mathrm{a}}$ significant at $\mathrm{p}<0.01$; ${ }^{\mathrm{b}}$ significant at $\mathrm{p}<0.05$.

In summary, we determined the conditions necessary to activate the immune system using leukemia apoptotic cells, in order to achieve effective recovery from leukemia in mice. These were (i) small mass (number) of leukemia cells, and (ii) activation of the immune system of mice with apoptotic leukemia cells containing neoantigens.

\section{Immune monitoring of cells in the human body}

Human lymphocytes regularly monitor the amino acid sequence of cytoplasmic and nuclear proteins within cells. The knowledge of these mechanisms began with experiments on the presence of proteinases within normal cells. The presentation of intracellular protein structure to cells of the immune system is associated with their degradation to peptides. These peptides are then associated with major histocompatibility complex (MHC) class I molecules, and the peptides of this complex are presented to lymphocytes on the surface of each cell (Fig. 1). The peptides are usually 8-mer to 12-mer peptides, produced within the proteasome [17-19]. Peptide aldehydes that inhibit major peptidase activities of the $20 \mathrm{~S}$ and $26 \mathrm{~S}$ proteasomes are shown to reduce the degradation of protein and ubiquitinated protein substrates. These compounds inhibit the degradation of abnormal (and also normal) proteins in intact cells, and may be used to test the importance of the proteasome in antigen presentation. Blockage of proteasomal activity within cells leads to apoptosis.

In our experiment, the proteasomal protease active within leukemia L1210 cells was tested by its inhibition using specific chymotrypsin inhibitor. Treatment of L1210 cells with inhibitor induced apoptosis (Fig. 2) [20]. The proteases are thus referred to as chymotrypsin-like (ChTr) proteases; they were present and active in the proteasomes of L1210 cells. Similar ChTr proteases have been observed in the other cancer cells,

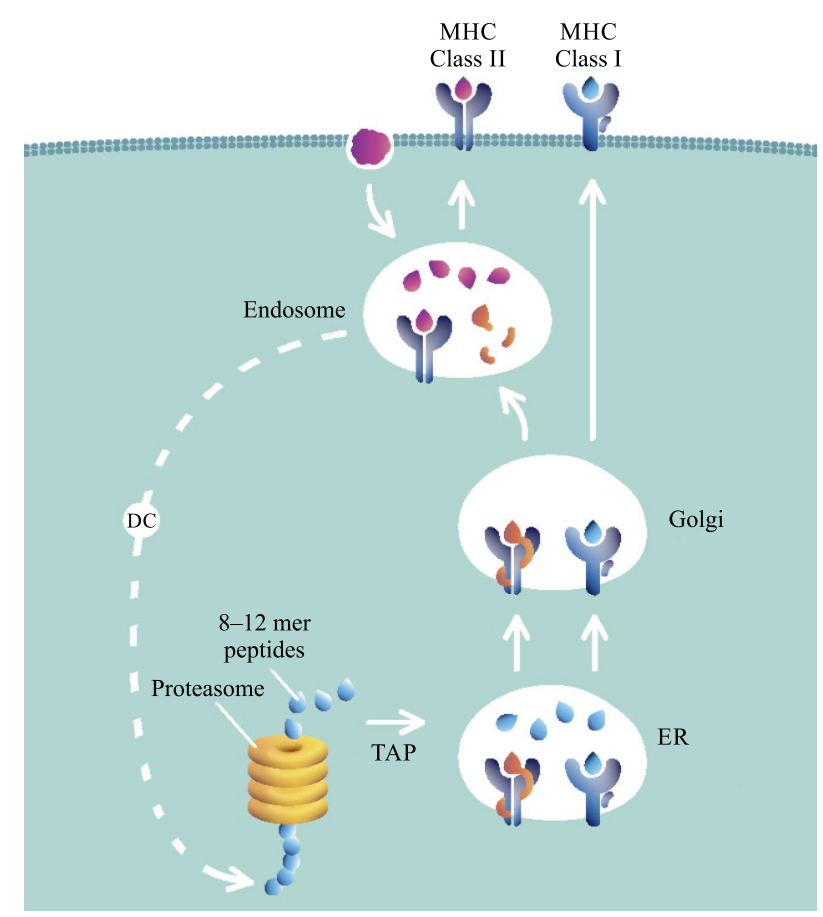

Figure 1. Schematic presentation of the mechanism of protein antigen processing in the proteasome and endosome and peptide presentation with MHCs in most cells in the human body. The proteasome-processed protein fragments are transported to the endoplasmic reticulum and bound to MHC class I, while endosome processed proteins are bound to MHC class II. Protein fragments with MHC are transported to the surface of cell. However, proteins from apoptotic cells or their fragments, phagocytosed by the dendritic cells (DC), are released from the endosome to cytoplasm, where they are processed in the proteasome and bound to MHC class I before being presented on the cell surface. $(---\rightarrow)$ pathway of antigens in the dendritic cell. TAP - transport associated processing; ER - endoplasmic reticulum.

as well as in the normal cells. The ChTr protease of the type present in proteasomes was isolated and purified, and its properties in normal mast cells have 

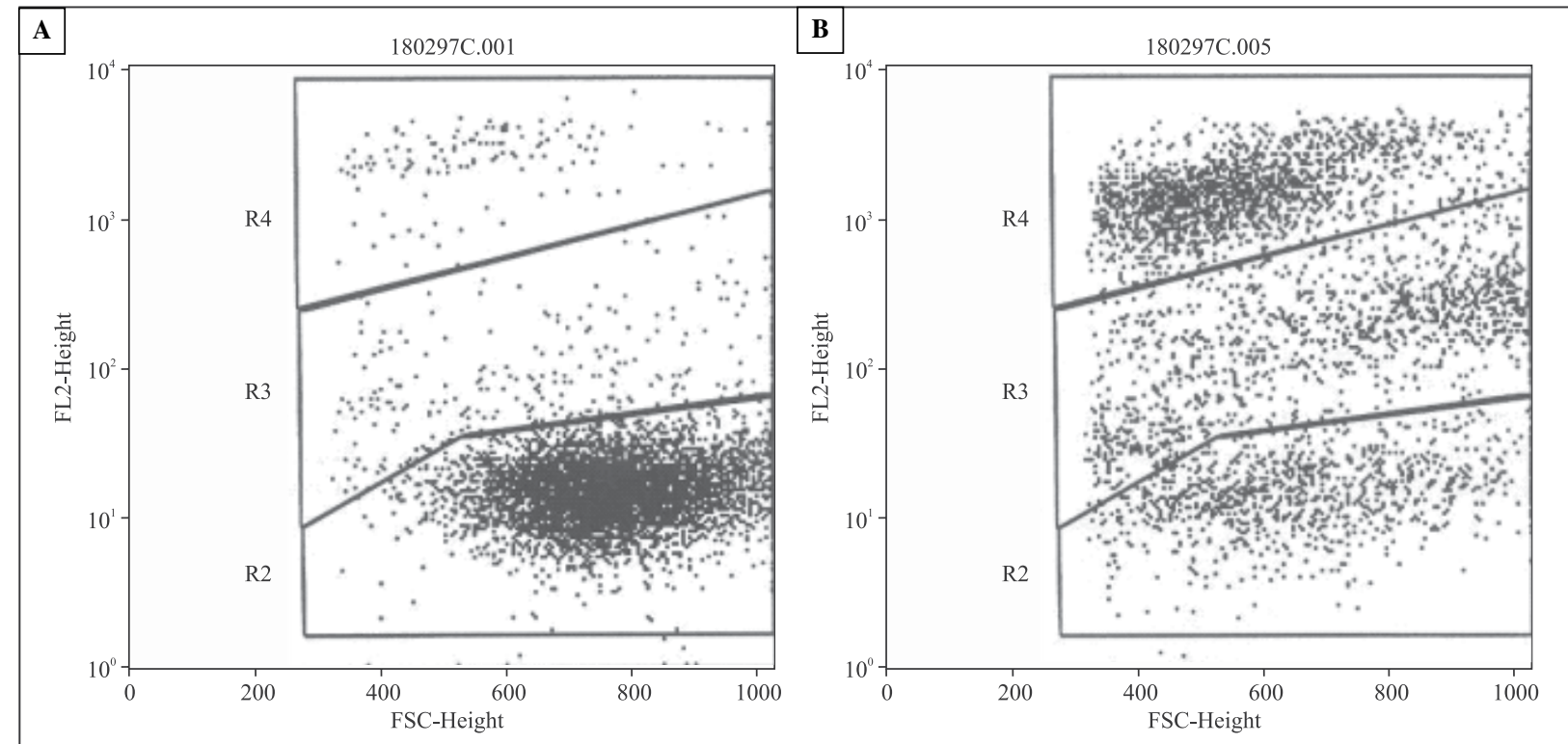

Figure 2. Inhibition of chymotrypsin-like protease in L1210 leukemia cells induces apoptosis of cells. Cells analyzed by the propidium iodide (PI) method in a control sample (A) and in the sample incubated for $24 \mathrm{~h}$ in the presence of $500 \mathrm{nM}$ PSI (chymotrypsin inhibitor) (B). Plot axes: FSC vs. FL2 (PI on $y$-axis). R2 living cells, R3 apoptotic cells, R4 necrotic cells [20].

been described [21]. It is well known that the $26 \mathrm{~S}$ proteasome is a multimeric complex consisting of a centrally located $20 \mathrm{~S}$ core catalytic complex flanked by $19 \mathrm{~S}$ regulatory subunits. The $20 \mathrm{~S}$ complex contains $\beta$ rings with three active enzymatic sites of distinct substrate specificities: chymotrypsin-like on the $\beta 5$ subunit, trypsin-like on the $\beta 2$ subunit, and caspaselike on the $\beta 1$ subunit [22].

Within the immune system, there is an active specialized type of cells called myeloid dendritic cells (mDCs), which have some additional functions in the presentation of peptide antigens. These mDCs have the additional property that their endocytotic membrane is capable of transporting part of the extracellular endocytosed proteins to the cytoplasm [23, 24], where they are processed by proteasomes of the phagocytosing cell. The phagocytosed extracellular protein peptides are then transported to the endoplasmic reticulum and presented to $\mathrm{T}$ lymphocytes with MHC class I on their cell surface. In this way, the exogenous antigens access the cytosol of $\mathrm{mDC}$ and are processed for presentation via the same pathway as described for conventional MHC class I restricted cytosolic protein antigens.

mDCs differentiate following phagocytosis of apoptotic cells and translocate to the lymph nodes $[25,26]$, where there are the optimal conditions for the presentation of cancer/leukemia antigens to naïve $\mathrm{T}$ cells constantly flowing (translocating) in the lymph. It has been described that $\mathrm{mDCs}$ remain and function within the lymph nodes over 2-3 weeks. This mean of presenting of mDCs is referred to as the crosspresentation of antigens, because with MHC class I not only are own-cell proteins presented, but so are the phagocytosed proteins of the apoptotic leukemia cells. We therefore suggest that the described recovery from leukemia of the mice treated with apoptotic L1210 leukemia cells was possible due to this process of crosspresentation of antigens in the phagocytosed cells by mDCs.

\section{Clinical attempts to activate antileukemia immunity}

The experiment in mice, with its conclusion that it is possible to activate the immune system to cure leukemia, was the basis for performing similar clinical tests in patients. Human chronic lymphocytic leukemia (B-CLL) is a hematologic neoplasm characterized by accumulation of a subpopulation of B-lymphocytes $\mathrm{CD} 19^{+} \mathrm{CD}^{+}$. The disease typically occurs over the age of 50 [27]. The clinical course of B-CLL is highly variable. When we first discussed the clinical experiment, the therapy of patients with the stable disease was limited to watching and waiting, coupled with treatment of disease-related symptoms: progressive marrow failure (anemia, thrombocytopenia), autoimmune complications, massive splenomegaly, lymphadenopathy, and infectious complications. Very precise prognostic diagnosis based on cytometric 


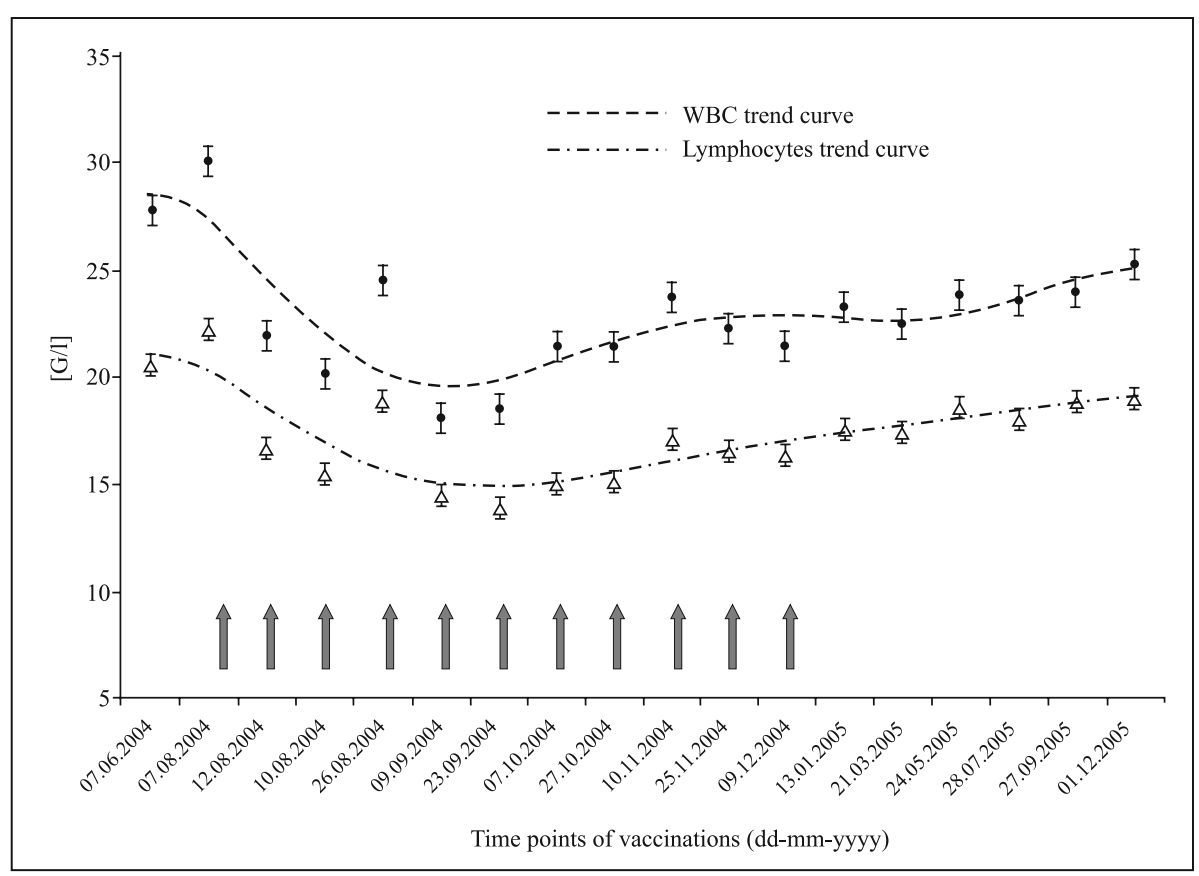

Figure 3. Leukocyte (WBC) and lymphocyte trend curves of a patient with B-CLL treated with irradiated leukemia cell vaccines from the time of initial diagnosis during immunotherapy to twelve months after the end of vaccination (patient from hematological improvement group) [37]. Arrows — time of vaccine injections.

analysis was required $[28,29]$. Chemotherapy and passive immunotherapy with monoclonal antibodies were also possible treatments. About 15 years ago, it was established that rituximab, a chimeric anti-CD20 monoclonal antibody, is effective when administered with chemotherapy. It was shown that rituximab significantly improves the outcome of both untreated and previously treated B-CLL patients [30-33]. Some other antibodies, such as ofatumumab, are also advised clinically [34].

The slow progress of B-CLL in some patients provides time for active immunotherapy. We therefore proposed to follow the treatment described earlier. Patients' consent was obtained, as was the agreement of the Ethical Commission at the School of Medicine, Lublin. It was assumed that B-CLL antigens could be crosspresented by mDCs. Preliminary results were presented in 2003 [35]. The clinical test was based on the use of the patient's CLL autologous apoptotic B-cells as a vaccine. The cells contained actual leukemia neoantigens of mutated proteins, with contents likely differing in different patients. We first performed tests in vitro, using gamma-irradiation doses to induce apoptosis in peripheral blood mononuclear cells (MNC) isolated from patients with B-CLL. The optimal radiation dose for inducing leukemia cells apoptosis in vitro was found to be $1000 \mathrm{~Gy}$ for 1 hour [8]. In different irradiated MNCs, the apoptosis process started hours or even days later, as shown by in vitro tests, which may be evidence of the variability of leukemia cells. The irradiated cells were given s.c. in the arm region near the lymph nodes. As irradiated cells begun to undergo the apoptotic process within few days, the procedure was repeated once a week, 11-12 times, to keep the leukemia antigen constantly exposed to the patient's immune system for a prolonged time. The procedure did not induce significant adverse effects, except for some small redness of the skin at the injection site, and sometimes a temperature rise of $1^{\circ} \mathrm{C}$ on the following day. Long-term observation of patients over a number of years did not disclose any adverse problems related to the vaccination $[36,37]$.

One positive outcome for patients during the vaccination, and for some 2-3 months longer, was a lower level of leukocytosis and lymphocytosis than they started with (Fig. 3). However, some patients (7 of 17) did not respond to the treatment, for which we have not explanation (Fig. 4). The most important difference, compared to the results of the animal in vivo experiment, was that there was no cure for patients with B-CLL. This could be expected as, during the long period of B-CLL development, the general mass of leukemia cells becomes large and the patient's immune system is constantly paralyzed. In our mice, L1210 leukemia was treated within a short time, and the leukemia cell mass (the number of L1210 cells) remained low. 


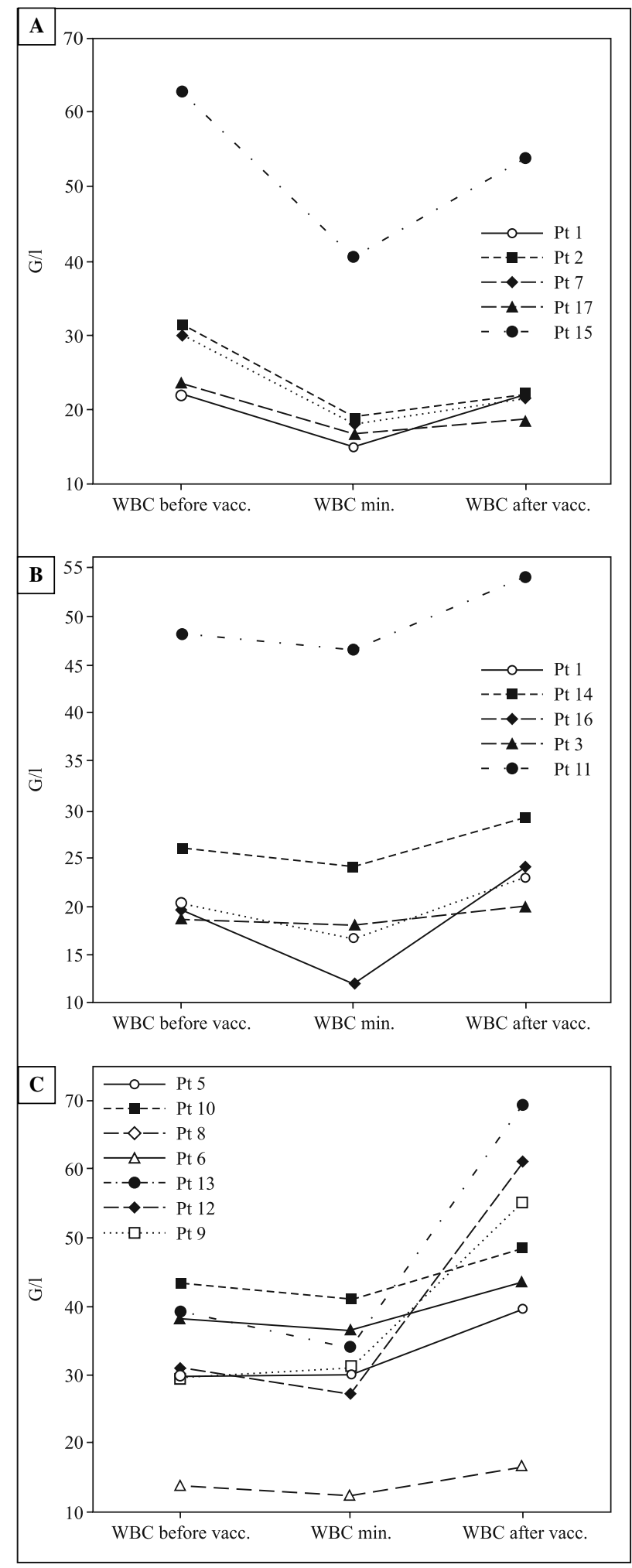

Figure 4. Summary of the vaccination results of 17 patients: (A) five responded with lower WBC (0.29), (B) five stabilized the increase of WBC (0.29) and (C) seven did not respond (0.41) [37].

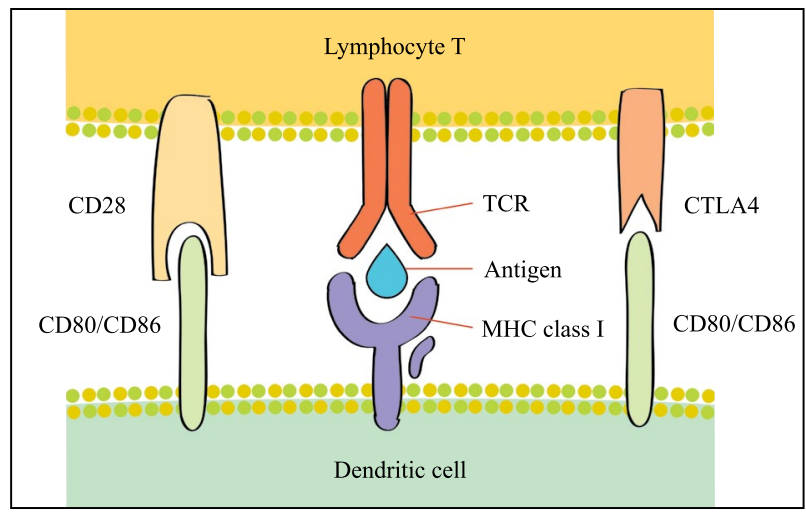

Figure 5. Schematic presentation of the activation of $T$ lymphocytes through recognition of the antigen presented with MHC class I and costimulation of the activated T cell necessary for exerting a cytotoxic effect on the target cell. There are two processes necessary for effector function of the T cell: recognition of the presented peptide antigen, and costimulation by interaction between CD80CD86 and CD28 on the lymphocyte. After some time, the checkpoint blocking protein CTLA4T appears on the T cell surface. Interaction of CTLA4 on the T cell with CD80CD86, however, blocks effector function. Moreover, CTLA4 has higher affinity to the CD80/CD86 than to CD28.

The following conclusions can be drawn from the clinical experiment: applied vaccination treatment cannot cure patient with B-cell chronic lymphocytic leukemia; however, in about two out of three patients, a delay in disease progression was observed for some period. These can be beneficial for the patient, as the well-known hematological problems (anemia, thrombocytopenia) are blocked for some time. New clones of Tlymphocytes directed against leukemia cells enlarge, and preserve the activation markers for a long time, as has been shown with cytometric analysis of peripheral blood leukocytes of vaccinated patients. However, the activated $T$ cells are cytotoxic to the recognized leukemia cells only for a short period of time (Fig. 5), as their costimulation is then blocked by the expression of checkpoint-blocking proteins such as CTLA4 (cytotoxic T-lymphocyte associated protein 4) or PD-1 (programmed cell death-1). Also, as part of the immune response in vaccinated patients, $T_{\text {reg }}$ cell clones are also rapidly enlarged and activated. The blocking of the $\mathrm{T}$ cell responses is probably the natural, physiological process that prevents long-term allergic activation. The vaccination did not lead to any undesired processes in patients, even after observation of some of them for 14 years. 


\section{Anticancer immune activation: More recent attempts}

The observation of patients with different cancer types now suggests some additional general conclusions. Immunological therapy in patients with cancer is rather of the passive type, involving the application of monoclonal antibodies. The chemotherapeutic pathway is intended to decrease the mass and lower the number of cancer cells, as well to block some known cellular regulatory processes. The active immunotherapy described here, based as it is on the activation of the immune T cells, involves recognizing the neoproteins of the mutated cancer cells. This should lead to better recognition of altered, mutated cells, allowing them to be more efficiently removed. This works for a period of time, but is then blocked by the expression of checkpoint blockers on activated lymphocytes [38-41]. In B-CLL, it can thus be proposed that complex associated active immunotherapy be used in conjunction with passive immunotherapy (rituximab), followed by antibodies that block the checkpoint blockers - e.g., directed at CTLA4 (ipilimumab) or PD-1 and its ligands [42, 43]. Promising clinical attempts to block the checkpoint blockers are now underway, so the application of complex associated active immunotherapy may soon appear as a promising therapeutic approach.

Long-term observations of both healthy individuals and B-CLL patients suggest that an important role is played in cancer immunity by the $\mathrm{T}$ lymphocyte subpopulations discussed above $\left(\mathrm{CD}^{+} \mathrm{CD}^{+}\right.$ and $\left.\mathrm{CD}^{+}{ }^{+} \mathrm{CD}^{+}\right)$recognizing infected or mutated cytoplasmic proteins within the cells. Mammalian $\mathrm{T}$ cells monitor the proteome of most cells; however, the lymphocyte subpopulation called NKT cells recognize another group of compounds in cells (lipids and glycolipids) and appear to be very important for the normal functioning and regulation of the immune system [44-46]. The activation of NKT cells is probably also important for cancer immunity. A subpopulation of these cells, iNKT cells, recognizes glycolipids presented by the nonpolymorphic CD1d antigen-presenting molecule [47]. These iNKT cells are capable of rapidly producing type Th1, Th2, and Th17 cytokines upon activation, as they store readyto-use cytokine mRNA. This shortens the route and time needed to cytokine production and release. The constant renewal, exchange, and activation of NKT cells may be maintained, as noted by several years of personal observations. These are induced by proper nutritional composition, containing lipids such as unsaturated fatty acids, omega-3, omega-6 lipids, and cod liver oil [46-50].
A system of vaccination, similar to ours, with autologous tumor cells for active specific immunotherapy, has also been presented by the other authors [51-54]. It seems that passive and active immunotherapy, supported by the additional activation of NKT cells, may help in preventing cancer in healthy persons, as well as curing for cancer patients.

In conclusion, the induction of apoptosis blocks cell proliferation. However, the apoptotic process, which takes about $2 \mathrm{~h}$ to complete once begun, is delayed by hours or days (4-5 days in irradiated B-CLL cells). Thus, the patient's leukemia cells form heterogenous population, as apoptosis starts at varius times after their induction in different cells. Vaccination with the actual cancer antigens of apoptosis-induced cells induces activation of several anticancer $\mathrm{T}$ cell clones. However, it was observed in B-CLL vaccinated patients that the response is blocked after 2-4 months or more, which probably results from the physiological checkpoint regulation of immune system function; this is undesirable in cancer treatment. The anticancer vaccination should thus be followed by passive immunotherapy by treatment that prevents immune checkpoint blocking. Recently, anti-PD-1 monoclonal antibodies, nivolumab (fully human IgG4 antibody), and pembrolizumab (humanized IgG4- $k$ antibody) have been approved for advanced kidney cancer $[55,56]$ and metastatic non-small-cell lung cancer (NSCLC), whose tumors express programmed death-ligand 1 (PD-L1) [54]. The treatment of B-CLL patients with anti-checkpoint blocker antibodies was unknown in 2003-2008 when we performed our study of apoptotic leukemia cell treatment in CLL patients. Since then, technological advances have led to the approval of immune checkpoint blocking monoclonal antibodies for the treatment of malignant lymphomas and B-CLL [57-60].

\section{Acknowledgments}

The author thanks his colleagues for several years of cooperation, the reviewer for help with the final text, and to Zofia Herbich for her assistance with the figures.

\section{References}

1. Geran RI, Greenberg NH, Macdonald MM, et al. Modified protocol for the testing of new synthetics in the L1210 lymphoid leukemia murine model in the DR\&D program, DCT, NCI. Natl Cancer Inst Monogr. 1977; 45: 151-153, indexed in Pubmed: 927490.

2. Kawiak J, Skórski T, Ciechanowicz A, et al. Cytochemical characterization of mouse L1210 leukemia. Immunol Invest. 1988; 17(6-7): 543-550, indexed in Pubmed: 2466781.

3. Fabisiewicz A, Pacholewicz K, Paszkiewicz-Kozik E, et al. Polymorphisms of DNA repair and oxidative stress genes in 
B-cell lymphoma patients. Biomed Rep. 2013;1(1): 151-155, doi: 10.3892/br.2012.31, indexed in Pubmed: 24648912.

4. Verdegaal EME, de Miranda NF, Visser M, et al. Neoantigen landscape dynamics during human melanoma-T cell interactions. Nature. 2016; 536(7614): 91-95, doi: 10.1038/ /nature18945, indexed in Pubmed: 27350335.

5. Lennerz V, Fatho M, Gentilini C, et al. The response of autologous T cells to a human melanoma is dominated by mutated neoantigens. Proc Natl Acad Sci U S A. 2005; 102(44): 16013-16018, doi: 10.1073/pnas.0500090102, indexed in Pubmed: 16247014.

6. Eil R, Vodnala SK, Clever D, et al. Ionic immune suppression within the tumour microenvironment limits $\mathrm{T}$ cell effector function. Nature. 2016; 537(7621): 539-543, doi: 10.1038/ /nature19364, indexed in Pubmed: 27626381.

7. Meyn RE, Stephens LC, Hunter NR, et al. Induction of apoptosis in murine tumors by cyclophosphamide. Cancer Chemother Pharmacol. 1994; 33(5): 410-414, indexed in Pubmed: 8306415 .

8. Tabarkiewicz J, Kawiak J. Start of apoptosis process observed in human irradiated B-CLL cells of peripheral blood. $1 \times 10^{7}$ MNC of the patient were suspended in $1 \mathrm{ml}$ of $0.9 \% \mathrm{NaCl}$, irradiated with 1000 Gy of $\gamma$-irradiation $\left({ }^{137} \mathrm{Cs}\right)$ using Gamma Cell 1000 Elite apparatus (Nordion International Inc. Canada), and start of apoptosis within cells was observed over the six following days. ; 2003: unpublished observations.

9. Davidoff AN, Mendelow BV. Cell-cycle disruptions and apoptosis induced by the cyclophosphamide derivative mafosfamide. Exp Hematol. 1993; 21(7): 922-927, indexed in Pubmed: 8319782.

10. Kerr JF, Wyllie AH, Currie AR. Apoptosis: a basic biological phenomenon with wide-ranging implications in tissue kinetics. Br J Cancer. 1972; 26(4): 239-257, indexed in Pubmed: 4561027.

11. Koopman G, Reutelingsperger CP, Kuijten GA, et al. Annexin $\mathrm{V}$ for flow cytometric detection of phosphatidylserine expression on B cells undergoing apoptosis. Blood. 1994; 84(5): 1415-1420, indexed in Pubmed: 8068938.

12. Kawalec M, Jakóbisiak M, Skórski T, et al. Immunogenicity of cyclophosphamide-treated leukaemia cells. Folia Biol (Praha). 1982; 28(5): 334-343, indexed in Pubmed: 6816636.

13. Kawalec M, Skórski T, Kawiak J. Successful chemoimmunotherapy of murine L1210 lymphatic leukemia with cyclophosphamide and mafosfamide-treated leukemia cells. Invest New Drugs. 1988; 6(3): 169-172, indexed in Pubmed: 3192382.

14. Kawalec M, Hoser G, Skórski T, et al. Immunogenic and nondividing mafosfamide-treated L 1210 cells--comparison of lines resistant and nonresistant to cyclophosphamide. Folia Histochem Cytobiol. 1993; 31(2): 63-66, indexed in Pubmed: 8405569.

15. Kawiak J, Kawalec M. Leukemia L 1210 cells induce depletion of Lyt 2+ thymocytes. Folia Histochem Cytobiol. 1990; 28(1-2): 15-17, indexed in Pubmed: 2097178.

16. Kawiak J, Kawalec M, Hoser G, et al. Changes of thymocyte subpopulations induced by activities diffusing from leukemia L1210 cells. Thymus. 1991; 18(3): 185-192, indexed in $\mathrm{Pu}-$ bmed: 1785132 .

17. Gaczynska M, Rock KL, Goldberg AL. Gamma-interferon and expression of MHC genes regulate peptide hydrolysis by proteasomes. Nature. 1993; 365(6443): 264-267, doi: 10.1038/365264a0, indexed in Pubmed: 8396732.

18. Aki M, Shimbara N, Takashina M, et al. Interferon-gamma induces different subunit organizations and functional diversity of proteasomes. J Biochem. 1994; 115(2): 257-269, indexed in Pubmed: 8206875.
19. Rock KL, Gramm C, Rothstein L, et al. Inhibitors of the proteasome block the degradation of most cell proteins and the generation of peptides presented on MHC class I molecules. Cell. 1994; 78(5): 761-771, indexed in Pubmed: 8087844.

20. Wójcik C, Stoklosa T, Giermasz A, et al. Apoptosis induced in L1210 leukaemia cells by an inhibitor of the chymotrypsin-like activity of the proteasome. Apoptosis. 1997; 2(5): 455-462, indexed in Pubmed: 14646528.

21. Kawiak J, Vensel W, Komender J, et al. Non-pancreatic proteases of the chymotrypsin family I. A chymotrypsin-like protease from rat mast cells. Biochim Biophys Acta. 1971; 235(1): 172-187, doi: 10.1016/0005-2744(71)90045-3.

22. Kimura H, Caturegli P, Takahashi $\mathrm{M}$, et al. New Insights into the Function of the Immunoproteasome in Immune and Nonimmune Cells. J Immunol Res. 2015; 2015: 541984, doi: 10.1155/2015/541984, indexed in Pubmed: 26636107.

23. Albert ML, Sauter B, Bhardwaj N. Dendritic cells acquire antigen from apoptotic cells and induce class I-restricted CTLs. Nature. 1998; 392(6671): 86-89, doi: 10.1038/32183, indexed in Pubmed: 9510252.

24. Brossart P, Bevan MJ. Presentation of exogenous protein antigens on major histocompatibility complex class I molecules by dendritic cells: Pathway of presentation and regulation by cytokines. Blood. 1997;90(4): 1594-1599, indexed in Pubmed: 9269778.

25. Lappin MB, Weiss JM, Delattre V, et al. Analysis of mouse dendritic cell migration in vivo upon subcutaneous and intravenous injection. Immunology. 1999; 98(2): 181-188, indexed in Pubmed: 10540216.

26. MartIn-Fontecha A, Sebastiani S, Höpken UE, et al. Regulation of dendritic cell migration to the draining lymph node: impact on Tlymphocyte traffic and priming. J Exp Med. 2003; 198(4): 615-621, doi: 10.1084/jem.20030448, indexed in Pubmed: 12925677.

27. Rozman C, Montserrat E. Chronic lymphocytic leukemia. N Engl J Med. 1995; 333(16): 1052-1057, doi: 10.1056/ /NEJM199510193331606, indexed in Pubmed: 7675049.

28. Poplawska-Szczyglowska L, Walewski J, Pienkowska-Grela B, et al. Chronic lymphocytic leukaemia presenting with central nervous system involvement. Med Oncol. 1999; 16(1): 65-68, indexed in Pubmed: 10382945.

29. Rawstron AC, Villamor N, Ritgen M, et al. International standardized approach for flow cytometric residual disease monitoring in chronic lymphocytic leukaemia. Leukemia. 2007; 21(5): 956-964, doi: 10.1038/sj.leu.2404584, indexed in Pubmed: 17361231.

30. Plosker GL, Figgitt DP. Rituximab: a review of its use in non-Hodgkin's lymphoma and chronic lymphocytic leukaemia. Drugs. 2003; 63(8): 803-843, indexed in Pubmed: 12662126

31. Robak T, Smolewski P, Cebula B, et al. Rituximab plus cladribine with or without cyclophosphamide in patients with relapsed or refractory chronic lymphocytic leukemia. Eur J Haematol. 2007; 79(2): 107-113, doi: 10.1111/j.16000609.2007.00889.x.

32. Tam CS, O'Brien S, Plunkett W, et al. Long-term results of first salvage treatment in CLL patients treated initially with FCR (fludarabine, cyclophosphamide, rituximab). Blood. 2014; 124(20): 3059-3064, doi: 10.1182/blood-2014-06-583765, indexed in Pubmed: 25281606.

33. Robak T, Dmoszynska A, Solal-Céligny P, et al. Rituximab plus fludarabine and cyclophosphamide prolongs progression-free survival compared with fludarabine and cyclophosphamide alone in previously treated chronic lymphocytic leukemia. J Clin Oncol. 2010; 28(10): 1756-1765, doi: 10.1200/ /JCO.2009.26.4556, indexed in Pubmed: 20194844. 
34. Bologna L, Gotti E, Da Roit F, et al. Ofatumumab is more efficient than rituximab in lysing B chronic lymphocytic leukemia cells in whole blood and in combination with chemotherapy. J Immunol. 2013; 190(1): 231-239, doi: 10.4049/ /jimmunol.1202645, indexed in Pubmed: 23225880.

35. Kawiak J, Rolinski J, Hus I, et al. Analysis of peripheral blood lymphocyte count in patients with B-cell chronic lymphocytic leukemia (B-cell CLL) treated (vaccinated) with own irradiated mononuclear cells. The case report. Acta Haematologica Pol. 2003; 34(suppl.1): 129.

36. Kawiak J, Hus I, Rolinski J, et al. Immunotherapy od B-CLL patients with autologous irradiated leukemic cells and BCG. Polish J. Environmental Studies. 2005; 14(suppl. II): 187-191.

37. Hus I, Kawiak J, Tabarkiewicz J, et al. Immunotherapy with irradiated autologous leukemic cells in patients with B-CLL in early stages. Oncol Rep. 2008; 20(2): 443-451, indexed in Pubmed: 18636210.

38. Kosmaczewska A, Ciszak L, Boćko D, et al. Expression and functional significance of CTLA-4, a negative regulator of T cell activation. Arch Immunol Ther Exp (Warsz). 2001; 49(1): 39-46, indexed in Pubmed: 11266089.

39. Ciszak L, Frydecka I, Wolowiec D, et al. Patients with chronic lymphocytic leukaemia (CLL) differ in the pattern of CTLA4 expression on CLL cells: the possible implications for immunotherapy with CTLA-4 blocking antibody. Tumour Biol. 2016; 37(3): 4143-4157, doi: 10.1007/s13277-015-4217-1, indexed in Pubmed: 26490985.

40. Ren Z, Guo J, Liao J, et al. CTLA-4 Limits Anti-CD20-Mediated Tumor Regression. Clin Cancer Res. 2017; 23(1): 193-203, doi: 10.1158/1078-0432.CCR-16-0040, indexed in Pubmed: 27354469.

41. Grzywnowicz M, Karabon L, Karczmarczyk A, et al. The function of a novel immunophenotype candidate molecule PD-1 in chronic lymphocytic leukemia. Leuk Lymphoma. 2015; 56(10): 2908-2913, doi: 10.3109/10428194.2015.1017820, indexed in Pubmed: 25682964.

42. Larkin J, Hatswell AJ, Nathan P, et al. The Predicted Impact of Ipilimumab Usage on Survival in Previously Treated Advanced or Metastatic Melanoma in the UK. PLoS One. 2015; 10(12): e0145524, doi: 10.1371/journal.pone.0145524, indexed in Pubmed: 26700304.

43. Postow MA, Chesney J, Pavlick AC, et al. Nivolumab and ipilimumab versus ipilimumab in untreated melanoma. $\mathrm{N}$ Engl J Med. 2015; 372(21): 2006-2017, doi: 10.1056/NEJMoa1414428, indexed in Pubmed: 25891304

44. Kaszubowska L, Piotrowska A, Siedlecka-Kroplewska K, et al. NKT cells as a connecting element between innate and adaptive immunity. Adv Cell Biol. 2013; 40(4): 697-724.

45. Brennan PJ, Tatituri RVV, Heiss C, et al. Activation of iNKT cells by a distinct constituent of the endogenous glucosylceramide fraction. Proc Natl Acad Sci U S A. 2014; 111(37): 13433-13438, doi: 10.1073/pnas.1415357111, indexed in $\mathrm{Pu}-$ bmed: 25197085.

46. Ferguson LR, Chen H, Collins AR, et al. Genomic instability in human cancer: Molecular insights and opportunities for therapeutic attack and prevention through diet and nutrition. Semin Cancer Biol. 2015; 35 Suppl: S5-SS24, doi: 10.1016/j. semcancer.2015.03.005, indexed in Pubmed: 25869442.

47. Rauch J, Gumperz J, Robinson C, et al. Structural features of the acyl chain determine self-phospholipid antigen recognition by a CD1d-restricted invariant NKT (iNKT) cell.
J Biol Chem. 2003; 278(48): 47508-47515, doi: 10.1074/jbc. M308089200, indexed in Pubmed: 12963715.

48. Murphy RA, Mourtzakis M, Chu QSC, et al. Nutritional intervention with fish oil provides a benefit over standard of care for weight and skeletal muscle mass in patients with nonsmall cell lung cancer receiving chemotherapy. Cancer. 2011; 117(8): 1775-1782, doi: 10.1002/cncr.25709, indexed in Pubmed: 21360698.

49. Murphy RA, Mourtzakis M, Mazurak VC. n-3 polyunsaturated fatty acids: the potential role for supplementation in cancer. Curr Opin Clin Nutr Metab Care. 2012; 15(3): 246-251, doi: 10.1097/MCO.0b013e328351c32f, indexed in Pubmed: 22366922.

50. Pappalardo G, Almeida A, Ravasco P. Eicosapentaenoic acid in cancer improves body composition and modulates metabolism. Nutrition. 2015; 31(4): 549-555, doi: 10.1016/j. nut.2014.12.002, indexed in Pubmed: 25770317.

51. Vermorken JB, Claessen AM, van Tinteren H, et al. Active specific immunotherapy for stage II and stage III human colon cancer: a randomised trial. Lancet. 1999; 353(9150): 345-350, doi: 10.1016/S0140-6736(98)07186-4, indexed in Pubmed: 9950438.

52. Harris JE, Ryan L, Hoover HC, et al. Adjuvant active specific immunotherapy for stage II and III colon cancer with an autologous tumor cell vaccine: Eastern Cooperative Oncology Group Study E5283. J Clin Oncol. 2000; 18(1): 148-157, doi: 10.1200/JCO.2000.18.1.148, indexed in Pubmed: 10623705.

53. Uyl-de Groot CA, Vermorken JB, Hanna MG, et al. Immunotherapy with autologous tumor cell-BCG vaccine in patients with colon cancer: a prospective study of medical and economic benefits. Vaccine. 2005; 23(17-18): 2379-2387, doi: 10.1016/j.vaccine.2005.01.015, indexed in Pubmed: 15755632.

54. Sathyanarayanan V, Neelapu SS. Cancer immunotherapy: Strategies for personalization and combinatorial approaches. Mol Oncol. 2015; 9(10): 2043-2053, doi: 10.1016/j.molonc.2015.10.009, indexed in Pubmed: 26548534.

55. Motzer RJ, Rini BI, McDermott DF, et al. Nivolumab for Metastatic Renal Cell Carcinoma: Results of a Randomized Phase II Trial. J Clin Oncol. 2015; 33(13): 1430-1437, doi: 10.1200/JCO.2014.59.0703, indexed in Pubmed: 25452452.

56. Sul J, Blumenthal GM, Jiang X, et al. FDA Approval Summary: Pembrolizumab for the Treatment of Patients With Metastatic Non-Small Cell Lung Cancer Whose Tumors Express Programmed Death-Ligand 1. Oncologist. 2016; 21(5): 643-650, doi: 10.1634/theoncologist.2015-0498, indexed in Pubmed: 27026676.

57. Wang Yi, Wu L, Tian C, et al. PD-1-PD-L1 immune-checkpoint blockade in malignant lymphomas. Annals of Hematology. 2017; 97(2): 229-237, doi: 10.1007/s00277-017-3176-6.

58. Grzywnowicz M, Karczmarczyk A, Skorka K, et al. Expression of Programmed Death 1 Ligand in Different Compartments of Chronic Lymphocytic Leukemia. Acta Haematol. 2015; 134(4): 255-262, doi: 10.1159/000430980, indexed in Pubmed: 26159545.

59. Kawiak J, Hoser G, Domagała-Kulawik J. Problems of Cancer Treatment. Part 2. Treatment Based on Modification of Anticancer Immunological Responses in Therapy. Advances in Cell Biology. 2017; 5(1), doi: 10.1515/acb-2017-0007.

60. Xu-Monette ZY, Zhou J, Young KH. PD-1 expression and clinical PD-1 blockade in B-cell lymphomas. Blood. 2018; 131(1): 68-83, doi: 10.1182/blood-2017-07-740993, indexed in Pubmed: 29118007. 